\title{
JAUNESNIOJO MOKYKLINIO AMŽIAUS VAIKŲ GYVENSENOS YPATU- MAI IR SVEIKATOS STIPRINIMAS ŠEIMOJE
}

\author{
Neringa Strazdienė $\dot{1}^{1}$, Birutė Strukčinskienè ${ }^{1}$, Sigitas Griškonis ${ }^{1,2}$ \\ ${ }^{1}$ Klaipédos universitetas, ${ }^{2}$ Klaipédos universitetine ligoninè
}

Raktažodžiai: jaunesniojo mokyklinio amžiaus vaikai, gyvensena, sveikatos stiprinimas, šeima.

\begin{abstract}
Santrauka
Jaunesniame mokykliniame amžiuje formuojasi vaiko asmenybè, sveikos gyvensenos ịpročiai, igyjamos žinios. Todèl labai svarbu sveikos ir saugios gyvensenos pagrindus padèti jau ankstyvoje vaikysteje. Šeima - svarbiausia vaiko artimiausios aplinkos dalis, formuojanti jo elgseną ir gyvenseną. Darbo tikslas - ištirti jaunesniojo mokyklinio amžiaus vaikų gyvensenos ir sveikatos stiprinimo šeimoje ypatumus. Taikyta apklausa raštu. Tyrime dalyvavo 530 tèvų, kurių vaikai mokosi 1-3 klasèse (79 metų). Nustatyta, kad dauguma tévų savo vaiko sveikatą linkę vertinti kaip labai gerą arba gerą. Tik apie penktadalio šeimų, auginančių jaunesniojo mokyklinio amžiaus vaikus, gyvenimo būdas aktyvus. Didelè tèvų dalis vaikų fizinei sveikatai stiprinti renkasi vitaminus bei maisto papildus, daugiau kaip pusė respondentų grūdina savo vaikus ir skatina judèti. Vaikų psichinès sveikatos puoselèjimo būdais dažniausiai ịvardijami bendravimas su vaiku ir bendras iškilusių problemų sprendimas. Darbo dienomis dauguma vaikų judriems žaidimams ir sportui lauke skiria 1-2 val., savaitgaliais šiai veiklai skiriama daugiau laiko. Prie kompiuterio ar televizoriaus iki 1 val. darbo dienomis praleidžia apie penktadalis mokinių, o savaitgaliais praleidžiamo laiko trukmė ilgeja. Apie penktadalis mokiniu visada laikosi dienotvarkès. Šiek tiek daugiau negu pusès jaunesniojo mokyklinio amžiaus vaiku miego pradžia darbo dienomis yra 20-21 val. Savaitgaliais vaiku miego pradžios laikas vėlinamas. Savaitgaliais labai maža vaikų dalis eina miegoti tuo pačiu metu kaip ir darbo dienomis.
\end{abstract}

Ivadas

Jaunesnis mokyklinis amžiaus tarpsnis svarbus asme- nybès formavimosi, psichikos ir fiziniu galiu intensyvios plètotès laikotarpis, kuomet igyjamos žinios, ugdomi igūdžiai, formuojasi ịpročiai, mokomasi pažinti save ir savo galimybes. Didžiausią ịtaką asmens sveikatai turi gyvenimo būdas, todèl labai svarbu sveikos ir saugios gyvensenos pagrindus padèti jau ankstyvoje vaikysteje. Šeima - svarbiausia vaiko artimiausios aplinkos dalis, formuojanti jo elgseną ir gyvenseną. İskiepytos vertybès, tèvų pamokymai ir patarimai yra pagrindas, kuris išlieka ilgam ir dažnai lemia viso vėlesnio gyvenimo kokybę $[1,2,10]$. Spartus gyvenimo tempas, nepakankamos tèvų žinios apie sveikatos saugojimą ir stiprinimą, neigiamos nuostatos sveikatos atžvilgiu, nepalanki socialinė aplinka tampa vaikų netinkamos gyvensenos ir nesveikatos priežastimi. Pasaulio sveikatos organizacijos (PSO), taip pat Lietuvos Respublikos Sveikatos apsaugos ministerijos (LR SAM) paskelbtuose pranešimuose nurodoma vis prastejanti vaikų sveikatos būklè. Dažniausiai negaluoja ikimokyklinio ir jaunesniojo mokyklinio amžiaus vaikai. Panašią tendenciją pastebi ir autoriai, analizuojantys vaikų sveikatos ir jos ugdymo problemas: higienos ịūdžių bei ịpročių formavimo $[8,13]$, mitybos $[4,7,9,12,16-19]$ bei fizinio aktyvumo $[2,3,5,6,11,14,16,20]$.

Pažintinis, socialinis ir emocinis vaiko vystymasis bus visavertis tik tuo atveju, jei šeimoje vyraus pozityvi aplinka, o tèvai skatins sveiką vaiko gyvenseną ir formuos atitinkamus ịgūdžius [8]. Taigi svarbu padidinti tėvų atsakomybę už savo vaikų sveikatą ir fizinę brandą [5].

Darbo tikslas - ištirti jaunesniojo mokyklinio amžiaus vaiku gyvensenos ir sveikatos stiprinimo šeimoje ypatumus.

\section{Tyrimo medžiaga ir metodai}

Atliktas kiekybinis tyrimas, taikyta apklausa raštu. Tyrimas vyko 2014 m. šešiose Klaipėdos m. ir Klaipédos apskrities pagrindinèse mokyklose. Apklausoje raštu dalyvavo 530 tèvų, kurių vaikai mokosi 1-3 klasėse (7 - 9 metų amžiaus). Tiriamuju grupé sudaryta netikimybinès tikslinès atrankos būdu, kurią sudare 308 moterys (58,5 proc.) ir 
222 vyrai (41,5 proc.). Tiriamujų amžius: iki 25 metų - 17 proc., 25-30 metu - 34 proc., 31-40 metu - 32,1 proc., daugiau nei 40 metu - 16,6 proc. Daugiau nei pusè (61,5 proc.) tyrime dalyvavusių respondentų gyvena mieste, apie trečdalis (35,5 proc.) gyvena kaimo gyvenvietėse. Pasiskirstymas pagal išsilavinimą: 14,3 proc. tyrime dalyvavusių respondentų turèjo pagrindinị išsilavinimą, 40 proc. - vidurinị išsilavinimą, 27,20 proc. - aukštaji kolegini išsilavinimą, 18,5 proc. - aukštaji universitetini išsilavinimą. Iš tyrime dalyvavusių respondentų 53,6 proc. augino mergaitę, likę 46,4 proc. augino berniuką. Anketą tėvams sudarẻ 25 klausimai. Duomenys apdoroti SPSS (21.0 versija). Ryšio stiprumas tarp ranginių kintamujų buvo tiriamas naudojant Spearmen'o koreliacijos koeficientą, Kruskal-Wallis testą.

\section{Tyrimo rezultatai ir jų aptarimas}

Tyrime siekta išsiaiškinti, kaip tèvai vertina savo vaikų sveikatą. Rezultatų analizè parodè, kad 19,3 proc. apklaustų tèvų savo vaiko sveikatą linkę vertinti kaip labai gerą, 60,2 proc. - kaip gerą, o 20,5 proc. - vaiko sveikatą linkę vertinti vidutiniškai. Vaiko sveikatos vertinimas statistiškai reikšmingai nesiskiria tyrimo dalyvių lyties atžvilgiu. Nu-

1 lentelė. Šeimos gyvenimo būdas

\begin{tabular}{|c|c|c|c|c|c|}
\hline Teiginiai & $\begin{array}{c}\text { Visiškai } \\
\text { nesutinku } \\
\%\end{array}$ & $\begin{array}{l}\text { Nesu- } \\
\text { tinku } \\
\%\end{array}$ & $\begin{array}{c}\text { Nei } \\
\text { sutinku, nei } \\
\text { nesutinku } \\
\% \\
\%\end{array}$ & $\begin{array}{c}\text { Sutin- } \\
\text { ku } \\
\%\end{array}$ & $\begin{array}{c}\text { Visiškai } \\
\text { sutinku } \\
\%\end{array}$ \\
\hline $\begin{array}{l}\text { Jūsų šeimos gyvenimo būdas } \\
\text { yra emociškai nestabilus t.y. } \\
\text { dažni nesutarimai ir ịtampa } \\
\text { tarp šeimos narių, konfliktai, } \\
\text { nesėkmės, nuovargis, pinigų } \\
\text { stygius ir kt. }\end{array}$ & 96,2 & 3,0 & 0,4 & 0,4 & 0,0 \\
\hline $\begin{array}{l}\text { Jūsų šeimos gyvenimo būdas } \\
\text { yra ịtemptas, t.y. dažna } \\
\text { laiko stoka šeimos nariams, } \\
\text { nuovargis, didelis gyvenimo } \\
\text { tempas darbe, } \\
\text { nuotaikų kaita ir kt. }\end{array}$ & 78,9 & 2,6 & 14,3 & 4,2 & 0,0 \\
\hline $\begin{array}{l}\text { Jūsų šeimos gyvenimo būdas } \\
\text { yra aktyvus, t.y. aktyvus } \\
\text { laisvalaikio praleidimas, } \\
\text { sportas, kelionės, išvykos } \\
\text { ir kt. }\end{array}$ & 64,5 & 1,9 & 17,4 & 8,7 & 7,5 \\
\hline $\begin{array}{l}\text { Jūsų šeimos gyvenimo būdas } \\
\text { yra ịprastas ir pastovus, t.y. } \\
\text { šeima derina laisvalaikio } \\
\text { leidimą ir poilsị, užsiima } \\
\text { fizine, kultūrine ir kt. veikla, } \\
\text { palaiko pastovų gyvenimo } \\
\text { ritmą. }\end{array}$ & 1,5 & 0,8 & 14,7 & 25,3 & 57,7 \\
\hline
\end{tabular}

statyti statistiškai reikšmingi skirtumai tarp aukštaji išsilavinimą ir pagrindinị bei vidurinị išsilavinimą turinčių tèvų $\left(\chi^{2}=32,912,11 \mathrm{~s}=6, p=0,000\right)$. Aukštajį išsilavinimą turintys tévai savo vaikų sveikatą vertina prasčiau nei pagrindinị ar vidurinị išsilavinimą turintys tèvai. Kritiškiausiai vaiko sveikatos būklę vertina universitetinį išsilavinimą turintys respondentai $(\mathrm{p}=0,048)$.

Tyrimo metu buvo domètasi, koks gyvenimo būdas šeimos, auginančios jaunesniojo mokyklinio amžiaus vaikus. Analizuojant tyrimo rezultatus (1 lentelè) nustatyta, kad 83 proc. (sutinku $-25,3$ proc., visiškai sutinku $-57,7$ proc.) šeimų tvirtina praktikuojančios ịprastą gyvenimo būdą. Aktyvų gyvenimo būdą praktikuoja 16,20 proc. (sutinku 8,7 proc., visiškai sutinku 7,5 proc.) šeimų.

Respondentai, kurie yra labiau linkę savo vaiko sveikatą vertinti gerai arba labai gerai, taip pat yra labiau linkę manyti, kad jų šeimos gyvenimo būdas yra aktyvus. Tarp požymių nustatytas ryšys yra silpnas $(r=0,434, p=0,000)$.

Tyrime siekta išsiaiškinti, kokiais būdais tèvai stiprina vaikų fizinę ir psichinę sveikatą? Tyrimo rezultatai rodo, kad 91,3 proc. tèvų kaip vieną iš būdų stiprinti vaikų fizinę sveikatą renkasi vitaminų bei maisto papildų vartojimą, 63 proc. tèvų renkasi grūdinimą, 55,5 proc. tèvų vaikų sveikatą stiprina skatindami judèti (3 pav.), 11,3 proc. - skatina daryti mankštas, 6,0 proc. - vartoja ekologiškus maisto produktus, 4,3 proc. - taiko vaikams masažus. Kitų galimų atsakymo variantų respondentai nepasirinko.

Savo vaiku psichinę sveikatą tèvai stiprina kartu su vaiku spręsdami jo problemas (94,3 proc.), bendraudami su vaiku (86,4 proc.), skatindami pasitiketi savimi (51,7 proc.), puoselédami teigiamas emocijas (42,3 proc.), mokydami savo vaikus valdyti emocijas (41,1 proc.).

Vaiko sveikatai palaikyti reikšmingas mitybos režimas. Tyrimo rezultatai (2 lentelè) rodo, kad visada reguliariai maitinasi darbo dienomis (33,2 proc.) ir savaitgaliais $(57,4$ proc.) šeimų. Dažnai reguliariai maitinasi darbo dienomis (34 proc.) ir savaitgaliais $(32,1$ proc.) šeimų. Nustatyta, kad tie respondentai, kurie 
tyrimo metu buvo linkę nurodyti, kad visada darbo dienomis reguliariai maitinasi, taip pat buvo linkę nurodyti, kad taip elgiasi ir savaitgaliais $(\mathrm{r}=0,622, \mathrm{p}=0,000)$.

Tik apie trečdalis apklaustų šeimų visada darbo dienomis $(33,2$ proc.) maitinasi reguliariai. Savaitgaliais visada tai daro apie pusè $(58,5$ proc.) apklaustų šeimų. Daugiau kaip pusè apklaustų respondentų dažnai darbo dienomis $(61,9$ proc.) ir savaitgaliais $(60,0$ proc.) maistą gamina namuose. Nustatyta, kad šeimos dažniau darbo dienomis nei savaitgaliais valgo kavinèse, greito maisto užkandinèse (30,9 proc. darbo dienomis ir 11,3 proc. savaitgaliais). Savaitgaliais kartais kavinėse, greito maisto užkandinèse valgo 71,0 proc. šeimų. Panaši dalis apklaustujų darbo dienomis $(60,8$ proc.) ir savaitgaliais $(60,0$ proc.) nors ir ne visada valgo reguliariai, bet stengiasi rinktis sveiką maistą. Tačiau apie pusè respondentų (54,3 proc.) darbo dienomis ir daugiau kaip pusè $(63,4$ proc.) savaitgaliais teigia, kad jų šeima dažnai valgo saldumynus. Tie respondentai, kurie nurodè, jog jų šeimos dažnai smaguriauja saldumynais, saldžiais gèrimais, taip pat buvo linkę nurodyti, kad taip elgiasi ir savaitgaliais $(\mathrm{r}=0,808, \mathrm{p}=0,000)$.

Tyrime domejjomés laiko, skiriamo ịvairioms veikloms darbo ir savaitgalio dienomis, trukme (3 lentelè).

Analizuojant duomenis išryškejjo, jog judriems žaidimams ir sportui lauke darbo dienomis 81,9 proc. vaiku skiria 1-2 val., savaitgaliais 75,9 proc. vaikų šiai veiklai

2 lentelè. Šeimos maitinimosi įpročiai darbo dienomis ir savaitgaliais

\begin{tabular}{|c|c|c|c|c|c|c|c|c|c|c|}
\hline & \multicolumn{5}{|c|}{ Darbo dienomis } & \multicolumn{5}{|c|}{ Savaitgaliais } \\
\hline & 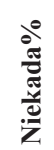 & 音 & فี & 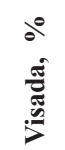 & 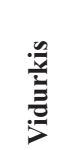 & $\frac{\overbrace{}^{\circ}}{\frac{\pi}{\tilde{E}}}$ & 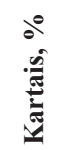 & 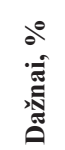 & 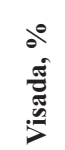 & 厸 \\
\hline $\begin{array}{l}\text { Jūsų šeima maitinasi } \\
\text { reguliariai } \\
\text { (valgomi pusryčiai, } \\
\text { pietūs, vakarienė). }\end{array}$ & 1,8 & 31,0 & 34,0 & 33,2 & 3,97 & 0,0 & 9,4 & 32,1 & 58,5 & 4,47 \\
\hline $\begin{array}{l}\text { Jūsǔ šeima valgo } \\
\text { kavinėse, greito } \\
\text { maisto užkandinėse, } \\
\text { maistas namuose } \\
\text { negaminamas. }\end{array}$ & 9,8 & 55,5 & 30,9 & 3,8 & 3,03 & 15,5 & 71,0 & 11,3 & 2,2 & 2,38 \\
\hline $\begin{array}{l}\text { Jūsų šeima maistą } \\
\text { gamina namuose } \\
\text { - produktai švieži, } \\
\text { sveiki. }\end{array}$ & 0,0 & 15,8 & 61,9 & 22,3 & 4,08 & 0,0 & 13,2 & 60,0 & 26,8 & 4,12 \\
\hline $\begin{array}{l}\text { Jūsų šeima nevalgo } \\
\text { reguliariai, tačiau } \\
\text { visada stengiasi rinktis } \\
\text { sveiką maistą. }\end{array}$ & 1,1 & 17,4 & 60,8 & 20,7 & 3,97 & 0,8 & 18,4 & 60,0 & 20,8 & 3,99 \\
\hline $\begin{array}{l}\text { Jūsų šeima sau leidžia } \\
\text { smaguriauti } \\
\text { saldumynais, saldžiais } \\
\text { gėrimais ir kt. }\end{array}$ & 2,3 & 41,5 & 54,3 & 1,9 & 3,43 & 0,8 & 34.0 & 63,4 & 1,8 & 3,60 \\
\hline
\end{tabular}

skiria 2 - 4 val. Prie kompiuterio ar televizoriaus iki 1 val. darbo dienomis laikydamiesi rekomenduojamų higienos normų praleidžia tik 23,4 proc. vaikų, šiek tiek daugiau nei pusė vaikų (56,6 proc.) praleidžia 2 val., likusi vaikų dalis (14,0 proc.) praleidžia 3-4 val. prie kompiuterio ar televizoriaus. Savaitgaliais prie kompiuterio ar televizoriaus praleidžiamo laiko trukmé ilgèja: 1 val. praleidžia 11,7 proc. mokinių, 2-5 ir daugiau val. - 88,3 proc. mokinių. Nustatyta, kad respondentų vaikai, kurie darbo dienomis prie televizoriaus ar kompiuterio praleidžia daug laiko, taip elgiasi ir savaitgaliais $(\mathrm{r}=0,583, \mathrm{p}=0,000)$.

Apie pusè respondentų vaikų (59,6 proc.) darbo dienomis aktyviai protinei veiklai skiria 3 val., savaitgaliais šiai veiklai skiriama šiek tiek mažiau laiko: 1 val. - 39,2 proc., 2 val. - 30,2 proc., 3 val. - 20,0 proc. mokinių. Tiesioginio ryšio tarp laiko skiriamo aktyviai protinei veiklai darbo dienomis ir savaitgaliais nenustatyta. Meninei veiklai (piešimui, grojimui ir kt.) vaikai tiek darbo dienomis, tiek savaitgaliais skiria laiko panašiai: 1-2 val. darbo dienomis skiria 77 proc. vaiku ir tiek pat laiko savaitgaliais skiria 83,7 proc. vaikų. Aktyviam laisvalaikiui su šeima savaitgalio dienomis skiriama daugiau laiko nei darbo dienomis: darbo dienomis 1 val. skiria 27,2 proc., 2 val. - 43,4 proc. ir 3 val. $-21,5$ proc. vaikų; savaitgaliais 2 val. $-15,5$ proc., 3 val. - 11,3 proc., 4 val. $-27,2$ proc. ir 5 val. $-31,7$ proc. vaikų. Tie respondentai, kuriu vaikai darbo dienomis ake tyviai leido laisvalaikị su šeima, nurodé, kad taip pat jų vaikai elgèsi ir savaitgaliais $(r=0,583$, $\mathrm{p}=0,000$ ).

Savaitgaliais pasyviam laisvalaikiui su šeima skiriama daugiau laiko nei darbo dienomis: darbo dienomis 1-3 val. skiria 93,9 proc. mokinių, savaitgaliais $2-5$ val. ir daugiau skiria 65,7 proc. mokinių.

Svarbus vaiko sveikatos stiprinimo elementas - teisingas dienotvarkès organizavimas. Tyrime siekème išsiaiškinti, ar vaikai laikosi dienotvarkès. Apie penktadalis mokinių (17,7 proc.) visada laikosi dienotvarkès. Daugiau kaip pusès $(63,1$ proc.) apklaustų tėvų vaikai dienotvarkès laikosi dažnai, o 8,3 proc. vaikų jos laikosi kartais, o 0,9 proc. vaiku jos visai nesilaiko. 
Apklausos metu buvo domètasi vaiko miego pradžios laiku darbo dienomis ir savaitgaliais. Šiek tiek daugiau nei pusès (51,3 proc.) jaunesniojo mokyklinio amžiaus vaikų miego pradžia darbo dienomis - 20-21 val. Panašiai tiek pat mokinių (48,3 proc.) darbo dienomis eina miegoti tarp 2122 val. ir tik 0,4 proc. mokinių eina miegoti po 22 val. Tačiau savaitgaliais, nepaisant higienos rekomendacijų, vaikų miego pradžios laikas vẻlinamas ir tik 3,4 proc. vaikų eina miegoti tuo pačiu metu kaip ir darbo dienomis tarp 20-22 val. Apie pusè $(46,4$ proc.) apklaustų tėvų vaikų savaitgaliais pradeda miegoti tarp $21-22$ val. ir net 50,2 proc. vaiku savaitgaliais pradeda miegoti po 22 val. Respondentai, kurių vaikai darbo dienomis eina miegoti po 22 val., taip pat ir savaitgaliais eina miegoti po 22 val. $(r=0,868 ; \mathrm{p}=0,000)$. Vadinasi, formuojasi ydingi vaiko miego ịpročiai, o miego pradžios vèlinimas sudaro sąlygas nepakankamam poilsiui ypač darbo dienomis.

Siekiant atskleisti vaikų sveikatos būklès situaciją, mūsų ir kitu atliktų tyrimų metu buvo tiriamas tèvų vertinimas apie jų vaikų sveikatą. S. Griškonio ir kt. [7] atliktas tyrimas atskleidè, kad pusè tėvų mano, jog jų vaiko sveikata gera. B. Strukčinskienès ir kt. [20] tyrime nustatyta, kad daugiau negu pusè tyrime dalyvavusių tėvų vaiko sveikatą vertino kaip gerą, o 23,2 proc. kaip labai gerą. R. Stuko ir kt. [17] atliktame tyrime dauguma tèvų taip pat vaiko sveikatą vertino teigiamai. Mūsų atliktame tyrime 19,3 proc. apklaustų tėvų savo vaiko sveikatą linkę vertinti kaip labai gerą, 60,2 proc. - kaip gerą, o 20,5 proc. - vaiko sveikatą linkę vertinti vidutiniškai.

Svarbi vaiku sveikatos stiprinimo sudedamoji dalis yra sveika mityba. Mokslinejje literatūroje pažymima, jog vaikų mityboje stokojama šviežių vaisių ir daržovių vartojimo. L. Dregval ir kt. [6] tyrime nustatyta, kad ikimokyklinio amžiaus vaikų šviežių daržovių ir vaisių suvartojimas yra nepakankamas. Bent kartą per dieną šviežias daržoves valgè du trečdaliai vaikų, tris kartus per dieną tik kas dvi-

3 lentelè. Vaiko skiriamas laikas ịvairioms veikloms darbo ir savaitgalio dienomis

\begin{tabular}{|c|c|c|c|c|c|c|c|c|c|c|c|c|}
\hline & \multicolumn{6}{|c|}{ Darbo dienomis } & \multicolumn{6}{|c|}{ Savaitgaliais } \\
\hline & 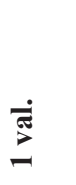 & 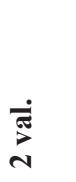 & $\stackrel{\infty}{\pi}_{m}^{\frac{\pi}{\pi}}$ & 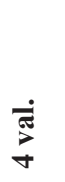 & 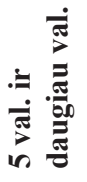 & 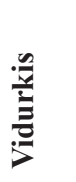 & 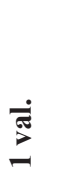 & $\underset{\sim}{\stackrel{\pi}{\pi}}$ & $\sum_{m}^{i}$ & 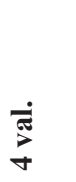 & 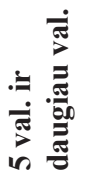 & 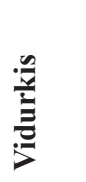 \\
\hline $\begin{array}{l}\text { Judrūs žaidimai, } \\
\text { sportas lauke. }\end{array}$ & 46,8 & 35,1 & 11,3 & 1,1 & 0,0 & 1,65 & 14,0 & 27,9 & 29,1 & 18,9 & 4,2 & 2,69 \\
\hline $\begin{array}{l}\text { Aktyvaus } \\
\text { fizinio judèjimo } \\
\text { reikalaujantys } \\
\text { būreliai, treniruotès. }\end{array}$ & 50,2 & 29,1 & 15,1 & 0,0 & 0,0 & 1,63 & 68,7 & 17,4 & 7,2 & 0,4 & 0,0 & 1,35 \\
\hline $\begin{array}{l}\text { Pasyvus laisvalaikis } \\
\text { prie televizoriaus ar } \\
\text { kompiuterio. }\end{array}$ & 23,4 & 56,6 & 13,6 & 0,4 & 0,0 & 1,90 & 11,7 & 35,5 & 26,0 & 23,8 & 3,0 & 2,69 \\
\hline $\begin{array}{l}\text { Aktyvi protinė veikla } \\
\text { - knygų skaitymas, } \\
\text { namų darbų ruoša } \\
\text { ir kt. }\end{array}$ & 2,6 & 29,1 & 59,6 & 1,9 & 0,0 & 2,65 & 39,2 & 30,2 & 20,0 & 3,8 & 0,0 & 1,87 \\
\hline $\begin{array}{l}\text { Ivairi meninė veikla } \\
\text { - piešimas, grojimas } \\
\text { ir kt. }\end{array}$ & 34,4 & 42,6 & 17,4 & 0,0 & 0,0 & 1,82 & 44,5 & 39,2 & 9,1 & 0,8 & 0,4 & 1,65 \\
\hline $\begin{array}{l}\text { Aktyvus laisvalaikio } \\
\text { leidimas su šeima } \\
\text { (išvykos, ekskursijos, } \\
\text { žaidimai ir kt.) }\end{array}$ & 27,2 & 43,4 & 21,5 & 1,9 & 0,0 & 1,98 & 8,3 & 15,5 & 11,3 & 27,2 & 31,7 & 3,62 \\
\hline $\begin{array}{l}\text { Pasyvus laisvalaikio } \\
\text { leidimas su šeima } \\
\text { (kino teatrų lankymas, } \\
\text { stalo žaidimai, } \\
\text { bendravimas ir kt.) }\end{array}$ & 26,4 & 47,5 & 20,0 & 0,0 & 0,0 & 1,93 & 9,4 & 18,5 & 19,6 & 24,2 & 21,9 & 3,33 \\
\hline
\end{tabular}


dešimtas vaikas. R. Stuko ir kt. [17] tyrimo rezultatai rodo, kad vaikai vaisių ir daržovių dažniausiai vartoja nepakankamai vieną arba du kartus per dieną. Mūsų atlikto tyrimo rezultatai parodè, kad tèvai sveikos mitybos, ị kurią ịtraukiamas vaisių ir daržovių vartojimas, nesieja su vaiko sveikatos stiprinimu. Tik 6,0 proc. respondentų vaiko sveikatos stiprinimą sieja su ekologiškų maisto produktų vartojimu.

Šeimos mitybos ịpročiai ir tèvų pavyzdys svarbūs formuojantis vaikų mitybos ịpročiams bei jiems suaugus, savarankiškai kuriant savo gyvenseną. Mūsų tyrimas parodè, jog tik apie trečdalis apklaustų šeimų visada darbo dienomis $(33,2$ proc.) maitinasi reguliariai. Savaitgaliais visada tai daro apie pusè (58,5 proc.) apklaustų šeimų. Analizuojant vaikų mitybos ypatumus, D. Šopagienès ir kt. [21] tyrime nustatyta, kad daugiau kaip $2 / 3$ vaiku $(71,2$ proc.) maitinasi 4 ir daugiau kartu per dieną, beveik trečdalis $(28,6$ proc.) - maitinasi tris kartus per dieną. S. Griškonio ir kt. [7] duomenimis, dauguma vaikų (72,78 proc.) valgo keturis ir daugiau kartų, o ketvirtadalis - tris kartus per dieną.

S. Griškonio ir kt. [7] duomenimis, dažniausiai vaikai i puodeli arbatos deda 1-2 šaukštelius cukraus. Puse tirtų vaikų (48,4 proc.) nededa visai ar deda ne daugiau kaip 1 šaukštelị cukraus.

Mūsų tyrimas rodo, jog apie pusė respondentų (54,3 proc.) šeimų darbo dienomis ir daugiau kaip pusé $(63,4$ proc.) savaitgaliais dažnai valgo saldumynus.

Vertinant mokinių dienotvarkę, vaikų sveikatai yra svarbūs fizinio aktyvumo, jo ir pasyvios veiklos santykis bei miego trukmès elementai. Tyrime domejjomés laiko, skiriamo įvairioms veikloms darbo ir savaitgalio dienomis, trukme. R. Stuko ir kt. [17] tyrime nustatyta, kad dauguma pradinių klasių mokinių gryname ore būna tik 1-2 val. per dieną. B. Strukčinskienè ir kt.[20] tyrime nustaté, kad tik 38 proc. jaunesniojo mokyklinio amžiaus vaikų pėsčiomis lauke vaikšto daugiau kaip 1 val. per dieną, o 14,4 proc. vaikų lauke vaikšto mažiau kaip 15 min. per dieną. Mūsų atlikto tyrimo duomenys patvirtina panašias tendencijas: judriems žaidimams ir sportui lauke darbo dienomis 81,9 proc. vaikų skiria 1-2 val., savaitgaliais 75,9 proc. vaikų šiai veiklai skiria 2 - 4 val.

R. Sketerskienès ir kt. [15] tyrimo duomenys parode, kad 60,3 proc. mokinių televizijai skiria 2-3 val., o 30,7 proc. vaikų apie 2 val. ir daugiau laiko praleidžia prie kompiuterio. R. Stuko ir kt. [19] tyrime dauguma vaiku televizijos laidas žiūri 1-2 val., penktadalis vaikų televizijos laidas žiūri 2-3 val. per dieną, visai televizijos laidų nežiūri tik 3 proc. vaikų. L. Dregval ir kt. [6] tyrimas atskleide, kad net du penktadaliai ikimokyklinio amžaiaus vaikų prie kompiuterio būna 1-2 val. Mūsų tyrimo duomenys rodo, jog prie kompiuterio ar televizoriaus iki 1 val. darbo di- enomis praleidžia tik 23,4 proc. vaikų, šiek tiek daugiau nei pusè vaikų (56,6 proc.) praleidžia 2 val., likusi vaikų dalis (14,0 proc.) praleidžia 3-4 val. prie kompiuterio ar televizoriaus. Savaitgaliais prie kompiuterio ar televizoriaus praleidžiamo laiko trukmè ilgèja: 1 val. praleidžia 11,7 proc. mokinių, $2-5$ ir daugiau val. $-88,3$ proc. mokinių.

Vertinant vaiku veiklos ir poilsio kaita pirmiausia svarbu atkreipti dèmesị ị miego rèžimo organizavimą šeimoje. R. Sketerskienès ir kt. [15] tyrime tik trečdalis mokinių nurode, kad darbo dienomis miega tiek, kiek rekomenduojama 9-10 val. Apie trečdalis mokinių nakties miegui darbo dienomis skiria tiek laiko, kiek rekomenduojama šio amžiaus vaikams. R. Stuko ir kt. [17] duomenimis, jaunesniojo mokyklinio amžiaus mokiniai miega per mažai - vidutinè paros miego trukmè tarp visų klasių mokinių yra 9 val. Mūsų tyrimas rodo, jog apie pusès (51,3 proc.) jaunesniojo mokyklinio amžiaus vaikų miego pradžia darbo dienomis 20-21 val. Panašiai tiek pat mokinių ( 48,3 proc.) darbo dienomis eina miegoti tarp 21-22 val. ir 0,4 proc. mokinių eina miegoti po 22 val. Kuo labiau vélinama miego pradžia, tuo mažiau vaikas miega nakties metu, nes pamokos pradiniụ klasių mokiniams dažniausiai prasideda 8.00 val. Savaitgaliais, nepaisant higienos rekomendacijų, vaikų miego pradžios laikas vélinamas ir tik 3,4 proc. vaikų eina miegoti tuo pačiu metu kaip ir darbo dienomis tarp 20-22 val.

\section{Išvados}

1. Dauguma tèvų savo vaiko sveikatą linkę vertinti kaip labai gerą arba gerą. Aukštajị išsilavinimą turintys tèvai savo vaikų sveikatą vertina prasčiau nei pagrindinị ar vidurinị išsilavinimą turintys tèvai.

2. Didelé tėvų dalis vaikų fizinei sveikatai stiprinti renkasi vitaminų bei maisto papildų vartojimą, daugiau kaip pusè respondentų grūdina savo vaikus ir skatina judèti. Tačiau tik apie penktadalis šeimų, auginančių jaunesniojo mokyklinio amžiaus vaikus, patys praktikuoja aktyvų gyvenimo būdą. Vaikų psichinès sveikatos puoselejjimo būdais dažniausiai ịvardijami bendravimas su vaiku ir bendras iškilusiu problemu spendimas. Darbo dienomis dauguma vaikų judriems žaidimams ir sportui lauke skiria 1-2 val., savaitgaliais šiai veiklai skiriama daugiau laiko. Prie kompiuterio ar televizoriaus iki 1 val. darbo dienomis praleidžia tik apie penktadalis mokinių, o savaitgaliais prie kompiuterio ar televizoriaus praleidžiamo laiko trukmè ilgèja.

3. Visada reguliariai darbo dienomis maitinasi apie trečdalis ir savaitgaliais apie puse apklaustų šeimų. Šeimos, kurios visada darbo dienomis maitinasi reguliariai, taip elgiasi ir savaitgaliais. Apie penktadalis mokiniu visada laikosi dienotvarkès, o apie pusè mokinių tai daro 
dažnai. Šiek tiek daugiau nei pusės jaunesniojo mokyklinio amžiaus vaikų miego pradžia darbo dienomis $-20-21$ val. Savaitgaliais vaikų miego pradžios laikas vèlinamas ir tik labai maža vaikų dalis eina miegoti tuo pačiu metu kaip ir darbo dienomis.

\section{Literatūra}

1. Adaškevičienè E. Vaikų fizinès sveikatos ir kūno kultūros ugdymas: monografija. Klaipėda: KU leidykla, 2004.

2. Adaškevičienė E., Strazdienė N. Vaikų sveikatą stiprinančio fizinio aktyvumo ugdymas: monografija. Klaipeda: KU leidykla, 2013.

3. Agazzi I, Armstrong K, Bradley-Klug KL. BMI and physical activity among at-risk sixth- and ninth-grade students, Hillsborough county, Florida, 2005-2006. Preventing Chronic Disease 2010; 7 (3): 1-9.

4. Eastwood M. Principles of Human Nutrition (second edition). Blackwell Publishers 2005.

5. Armonienė J. Mokinių fizinis aktyvumas ir sveikata. Mokslo darbai. Pedagogika, 2007; 85: 196-203.

6. Dregval L., Malinauskaitė V. Pirmokų fizinio aktyvumo priklausomybė nuo socialinių-ekonominių veiksnių. Ugdymas. Kūno kultūra. Sportas, 2008; 4(71):29-36.

7. Griškonis S., Strukčinskienė B., Strazdienė N. Vakarų Lietuvos ikimokyklinio amžiaus vaikų mitybos ypatumai: Šilutės rajono atvejis. Sveikatos mokslai, 2011; 21 (4): 42-47.

8. Kulbokienė R. Sveikata kaip harmoningo žmogaus ugdymo prielaida. Nuo idejos iki rezultato: konferencijos, vykusios 2005 m. 12 mèn. 6 d. medžiaga ir metodinès rekomendacijos sveikatą stiprinantiems darželiams, Kaunas, 2005.

9. Lažauskas R. Mityba ir sveikata. Kaunas: KMU leidykla, 2005.

10. Minkuvienè E. (Sud.). Priešmokyklinis ugdymas ir pradinė mokykla: patirtis, idejjos. Šiauliai: K.J. Vasiliausko įmonè, 2003.

11. O'Connor A. Promoting healthy eating and an active lifestyle in schoolchildren. Nursing Standard 2011; 25: 45-56. http://dx.doi.org/10.7748/ns2011.08.25.48.48.c8649

12. Proškuvienè R. Mityba. Judejjimas. Vilnius: Vilniaus pedagoginis universitetas, 2006.

13. Wiater HA, Mitschke RA, Widdern S. Sleep Disorders and Behevioural Problems among 8 to 11 Yers-old Children. Blackwell Verlag, Berlin 2005; 9: 210-214.

14. Riech S.K., Anderson L.S., Krueger H.A. Parent - Child Communication Processes: preventing Childrens Health Risk Behavior. Journal for Specialists in Pediatric Nursing 2006; 11: 41-56. http://dx.doi.org/10.1111/j.1744-6155.2006.00042.x

15. Sketerskienė R., Šurkienė G., Žagminas K. Mokinių mokymosi krūvio bei sveikatos ir dienos rèžimo sąsajos. Medicina, 2009; 45(5): 395-404.

16. Strazdienė N. Vaikų sveikos mitybos įpročių ugdymas pradinėje mokykloje: mokytojų nuomonè. Tiltai, 2014; 1(67): 67-85. http://dx.doi.org/10.15181/tbb.v66i1.779

17. Stukas R., Kalibatienė D., Vingras A. ir kt. Vilniaus miesto pradinių klasių mokinių gyvensena ir sveikata. Medicinos teorija ir praktika, 2011; 4 (17):430-436.

18. Sturgeon N, Robinson S, Maxwell S. Healthy Eating, Active Living: An action plan to improve diet, increase physical activity and tackle obesity (2008-2011). Edinburgh: The Scottish Government 2008.

19. Strukčinskaitè V., Tarvydienė N., Strukčinskienė B. Klaipėdos rajono ikimokyklinio amžiaus vaikų gyvensena: mitybos ypatumai. Visuomenès sveikata, 2013; 1(60): 43-47.

20. Strukčinskienė B., Raistenskis J., Šopagienė D., Kurlys D., Stasiuvienė D., Griškonis S., Radžiuvienė R. Vaikų fizinis aktyvumas ir sveikata, Klaipėda: S. Jokužio leidykla, 2012.

21. Šopagienė D., Strukčinskienė B., Stasiuvienė D. ir kt. Ikimokyklinio amžiaus vaikų mitybos ypatumai Klaipėdos mieste. Sveikatos mokslai, 2013; 1 (23), 37-41.

\section{PRIMARY SCHOOL CHILDREN'S LIFESTYLE AND HEALTH PROMOTION AT FAMILY LEVEL \\ N. Strazdienė, B. Strukčinskienė, S. Griškonis}

Key words: primary school children, lifestyle, health promotion, family.

Summary

At younger school age it is forming a child personality, lifestyle habits, and children acquire necessary knowledge. Therefore, it is of importance to assist for a healthy and safe way of life in the early childhood. The family is a most important part of the child environment. Family forms health foundations, orienting and forming the behaviour and the lifestyle. The objective of the study was to investigate the primary school children's living and health peculiarities at family level. A survey was conducted, and 530 parents of primary school children of 1-3 forms (aged 7 to 9 years) were investigated. It was found that the majority of parents tend to evaluate health of their children as very good or good. Only about one-fifth of families, growing primary school age children, live active lifestyle.

A large part of parents for enhancing children's physical health use vitamins and food supplements; more than half of the respondents toughen their children, and promote physical activities. Children's mental health promotion ways are communication with the child and common decisions of the problems that arise. It was found that the families more often on weekdays than on weekends are eating in cafes, and in fast-food eateries. On weekdays, most of children for active games and outdoors sport spend about 1-2 hours, on weekends for these activities they allocate more time. On weekdays, about one-fifth of children spend up to 1 hour by computer or TV, and on weekends, this duration is longer. About one-fifth of children always follow up the agenda. A little more than half of primary school children go to bed at 20-21 o'clock. On weekends, children go to bed later, and only a very small percentage of children go to bed at the same time as on weekdays.

Correspondence to: n.strazdiene@gmail.com

Gauta 2015-07-17 